\title{
Role of Local Prostaglandin Synthesis in the
}

\section{Modulation of Proliferative}

\section{Activity of Rat Colonic Epithelium}

\author{
Patricia A. Craven, Reisuke Saito, and Frederick R. DeRubertis, \\ Departments of Medicine and Pathology, Veterans Administration Medical \\ Center and University of Pittsburgh, Pennsylvania 15240
}

A B S T R ACT The role of local prostaglandin (PG) synthesis in the modulation of the proliferative activity of colonic epithelium was examined in rat colon. Experimental rats were given either indomethacin (5 $\mathrm{mg} / \mathrm{kg}$ s.c. every $8 \mathrm{~h}$ for three doses) or aspirin $(0.5$ $\mathrm{g} / 100 \mathrm{~g}$ diet for $3 \mathrm{~d}$ ). In rats treated with indomethacin or aspirin, the incorporation of $\left[{ }^{3} \mathrm{H}\right]$ thymidine (dThd) into DNA in vivo was increased approximately twofold over control in mucosal scrapings from distal colon, and approximately threefold over control in the proliferating pool of epithelial cells isolated from distal colon. $\left[{ }^{3} \mathrm{H}\right] \mathrm{dTh}$ incorporation into DNA was also examined ex vivo immediately after distal colonic resection. It was approximately twofold higher in mucosa of colonic segments (1-h incubation) from rats treated with indomethacin or aspirin in vivo, compared with corresponding values of segments from control rats. Immunoreactive (i) prostaglandin E (PGE), the dominant PG product of colon segment incubates by high-performance liquid chromatography analysis of $\left[{ }^{14} \mathrm{C}\right]$ arachidonate metabolites, was markedly (95\%) reduced in the media of $1-\mathrm{h}$ colon incubates from indomethacin- or aspirin-treated rats, compared with control rats. Moreover, the cyclic (c)AMP content of mucosa of segments from indomethacin- or aspirintreated rats was significantly lower than that of control rats. Prolonged incubation (4-24 h) of colonic segments from indomethacin-treated rats, in the absence of indomethacin in vitro, led to an eventual return of $\left[{ }^{3} \mathrm{H}\right] \mathrm{dTh}$ incorporation into DNA, iPGE, and mucosal cAMP to control values. Conversely, inclusion of indomethacin $(0.25 \mathrm{mM})$ in the incubations $(6 \mathrm{~h})$ of co-

Address all correspondence to Dr. Frederick R. DeRubertis.

Received for publication 1 April 1983 and in revised form 28 June 1983. lonic segments from indomethacin-treated rats resulted in persistent suppression of iPGE and mucosal cAMP, as well as persistent enhancement of $\left[{ }^{3} \mathrm{H}\right] \mathrm{d}$ Thd incorporation into mucosal DNA. However, incubation of colonic segments from control rats (no in vivo drug exposure) with indomethacin or aspirin in vitro for periods up to $24 \mathrm{~h}$ failed to alter DNA synthesis, despite marked reduction in media iPGE and lower mucosal cAMP. The latter observations suggested that additional in vivo factors initiated the enhancement of DNA synthesis in indomethacin- or aspirin-treated rats. Exogenous $\mathrm{PGE}_{2}, \mathrm{D}_{2}, \mathrm{I}_{2}$, or $\mathrm{F}_{2 \alpha}$, each of which increased the endogenous mucosal cAMP content of incubated colonic segments from control, indomethacin- or aspirin-treated rats, all suppressed $\left[{ }^{3} \mathrm{H}\right] \mathrm{d}$ Thd incorporation into mucosal DNA in vitro. Dibutyryl cAMP, but not dibutyryl cGMP, had an analogous suppressive effect on in vitro $\left[{ }^{3} \mathrm{H}\right] \mathrm{dTh}$ incorporation into DNA. Thus, the present observations are consistent with an inhibitory action of endogenous colonic PG synthesis on the proliferative activity of colonic epithelium. This action may be mediated through cAMP.

\section{INTRODUCTION}

The colon is an active site of prostaglandin $(\mathrm{PG})^{1}$ synthesis $(1,2)$. There is evidence that PG may modulate colonic transport functions (3) and motility (4). Studies of both rabbit and rat colonic explants in culture have also indicated that PG can alter the proliferative activity of normal colonic epithelium $(5,6)$. Thus, ad-

\footnotetext{
${ }^{1}$ Abbreviations used in this paper: DBcAMP, dibutyryl cyclic AMP; DBcGMP, dibutyryl cyclic guanosine monophosphate; $\left[{ }^{3} \mathrm{H}\right] \mathrm{dThd},\left[{ }^{3} \mathrm{H}\right]$ thymidine; HPLC, high-performance liquid chromatography; iPGE, immunoreactive prostaglandin E; PG, prostaglandin, $\mathrm{TXB}_{2}$, thromboxane $\mathrm{B}_{2}$.
} 
dition of exogenous $\mathrm{PGE}_{2}$ or $\mathrm{PGF}_{2 \alpha}$ to cultured explants suppresses mucosal DNA synthesis, possibly through the action of these agents to increase epithelial cyclic (c)AMP levels $(5,6)$. Attempts have also been made to assess the influence of PG on colonic epithelial proliferation in vivo. It has been reported that acute parenteral administration of the PG analogs 16,16-dimethyl $\mathrm{PGE}_{2}$ or 16,16-dimethyl-PGF ${ }_{2 \alpha}$ failed to alter the proliferative activity of colonic crypt epithelium in normal rats when assessed $4 \mathrm{~h}$ after injection of these agents (7). Similarly, the cyclooxygenase inhibitor flubiprofen was without apparent effect on the proliferative activity of colonic crypts, when assessed $4 \mathrm{~h}$ after injection of this drug (7). These negative results are difficult to interpret, since $(a)$ no evidence was provided that the systemic administration of either of the PG analogs or the cyclooxygenase inhibitor altered local colonic PG levels; and (b) proliferative activity was examined only after a brief period of in vivo exposure to the test agents. In more recent studies, Johansson et al. (8) reported that daily oral administration of $15(R) 15$-methyl-PGE 2 to rats for $14 \mathrm{wk}$ increased colonic mucosal height. Although cell kinetics and proliferative activity were not examined, the authors suggested that $\mathrm{PGE}_{2}$ might prolong cell turnover time by preventing exfoliation.

In the present in vivo and ex vivo study, we examined the effects of two structurally distinct cyclooxygenase inhibitors, indomethacin and aspirin, on DNA synthesis of colonic mucosa of normal rats, and correlated these effects with changes in colonic PG formation and mucosal cyclic nucleotide levels.

\section{METHODS}

Treatment of rats. Female Sprague-Dawley rats (ZivicMiller Laboratories, Pittsburgh, PA) were studied in two groups of six rats each. In studies with indomethacin, one group was given the indomethacin vehicle $(50 \mathrm{mM}$ Tris, $\mathrm{pH}$ 7.4) and the other indomethacin ( $5 \mathrm{mg} / \mathrm{kg}$ body $\mathrm{wt}$ ) by subcutaneous injection at 8 -h intervals over $24 \mathrm{~h}$. In studies with aspirin, groups of six rats were fed aspirin $(0.5 \mathrm{~g} / 100 \mathrm{~g}$ diet $)$ for $3 \mathrm{~d}$ and compared with controls fed standard rat chow without additions. This duration of aspirin ingestion was chosen on the basis of preliminary data demonstrating that it resulted in consistent ex vivo suppression of colon PG synthesis (see below). A portion of the colon from control and indomethacin- and aspirin-treated rats was routinely examined histologically by light microscopy. In preliminary experiments, injection of the $50 \mathrm{mM}$ Tris, indomethacin vehicle was shown to have no effect on in vivo or ex vivo $\left[{ }^{3} \mathrm{H}\right]$ thymidine (dThd) incorporation into DNA (see below) compared with values observed in untreated rats serving as controls in studies with aspirin. Accordingly, for purposes of statistical analysis and conciseness in presentation of the data, values obtained from untreated control rats were combined with those for groups treated with the Tris vehicle.

Determination of in vivo incorporation of $\left[{ }^{3} \mathrm{H}\right] \mathrm{dThd}$ into DNA. $\left[{ }^{3} \mathrm{H}\right] \mathrm{dThd}(50 \mu \mathrm{Ci} / \mathrm{rat})$ was injected intraperitoneally
$1 \mathrm{~h}$ after the final indomethacin injection or $72 \mathrm{~h}$ after introduction of aspirin. $2 \mathrm{~h}$ later, rats were anesthetized with pentobarbital $(50 \mathrm{mg} / \mathrm{kg}$ i.p.) and the distal colon resected from the colonic flexure to $1 \mathrm{~cm}$ above the anal orifice. Colons were placed in saline $\left(4^{\circ} \mathrm{C}\right)$ containing $30 \mathrm{mg}$ penicillin and $5 \mathrm{mg}$ gentamicin per $100 \mathrm{ml}$. In some studies, the mucosa was immediately scraped from the freshly excised colons. In other experiments, superficial and proliferative colonic epithelial cells were isolated, as previously described in detail (9), by a modification of the method of Weiser (10) for isolation of small intestinal epithelial cells. The pooled surface cell fractions used in the current study contained 17$25 \%$, while the pooled proliferative cell fractions contained $65-68 \%$ of the total recovered protein and DNA. $\left[{ }^{3} \mathrm{H}\right] \mathrm{dTh}$ incorporation into DNA, after in vivo $\left[{ }^{3} \mathrm{H}\right] \mathrm{d}$ Thd injection as described above, was four- to sevenfold higher in the pools of isolated proliferative cells used in the current study compared with that in the isolated surface cells. Greater than $\mathbf{9 5 \%}$ of the isolated cells were viable, as determined by trypan blue exclusion.

Determination of ex vivo incorporation of $\left[{ }^{3} \mathrm{H}\right] d \mathrm{Thd}$ into DNA, cyclic nucleotide content, and immunoreactive (i)PGE formation. The effects of treating rats in vivo with indomethacin or aspirin on colonic mucosal DNA synthesis, cAMP and cyclic guanosine monophosphate (cGMP) content, and iPGE formation by colonic segments were examined ex vivo. In these studies, rats were treated exactly as described above for analysis of in vivo $\left[{ }^{3} \mathrm{H}\right] \mathrm{d}$ Thd incorporation into DNA, except that no injection of $\left[{ }^{3} \mathrm{H}\right] \mathrm{d}$ Thd was given. In the ex vivo studies of $\left[{ }^{3} \mathrm{H}\right] \mathrm{dTh}$ incorporation into DNA, eight colonic segments $(1 \times 1 \mathrm{~cm})$ were prepared from each distal colon obtained from various treatment groups. Five segments were used for determination of $\left[{ }^{3} \mathrm{H}\right] \mathrm{dThd}$ incorporation into mucosal DNA, while three additional segments were incubated concurrently for determination of mucosal cAMP, cGMP, and media iPGE content. Incubations were begun within 15 min of resection and conducted for timed intervals (1-24 h) in $2 \mathrm{ml}$ of medium 199-bicarbonate containing $30 \mathrm{mg} \%$ penicillin, $5 \mathrm{mg} \%$ gentamicin and $10 \%$ (vol/vol) heat-treated $\left(56^{\circ} \mathrm{C}\right.$ for $\left.60 \mathrm{~min}\right)$ fetal bovine serum (medium 199-incubation buffer). The incubation buffer was routinely equilibrated with $95 \% \mathrm{O}_{2}, 5 \% \mathrm{CO}_{2}$. Indomethacin $(0.25 \mathrm{mM})$ or aspirin $(0.5 \mathrm{mM})$ was present in the media only where indicated in the Results. $\left[{ }^{3} \mathrm{H}\right] \mathrm{dThd}(0.5 \mu \mathrm{Ci} / \mathrm{ml})$ was added to some of the incubates for the times specified in Results. Incubations were conducted at $37^{\circ} \mathrm{C}$ in a Dubnoff metabolic shaker. In the 6 - $\mathrm{h}$ incubations described, media were changed at 2 -h intervals. Consistent with earlier results (6), the rate of uptake of $\left[{ }^{3} \mathrm{H}\right] \mathrm{dTh}$ into DNA was linear for $6 \mathrm{~h}$ when examined in segments from control or indomethacin- or aspirin-treated rats.

For determination of mucosal cAMP and cGMP content and iPGE accumulation in the incubation media, three segments from each colon were incubated at $37^{\circ} \mathrm{C}$ for timed intervals from $l$ to $6 \mathrm{~h}$ as described above, except that $\left[{ }^{3} \mathrm{H}\right] \mathrm{d}$ Thd was omitted from the incubate. Only media iPGE was assayed, since previous studies had demonstrated that virtually all ( $>90 \%$ ) of total incubate iPGE is found in the media (2). In separate studies of the time course of mucosal cAMP accumulation in colon segments incubated with exogenous PG, cAMP responses were examined at 5, 10, and $30 \mathrm{~min}$ and 1 and $6 \mathrm{~h}$ after addition of the PG.

Determination of $c A M P$ and $c G M P$. The cAMP and cGMP content of mucosal scrapings was extracted with 50 $\mathrm{mM}$ sodium acetate $\mathrm{pH} 4.0(50 \mathrm{mg}$ wet $\mathrm{wt} / 0.5 \mathrm{ml})$ at $95^{\circ} \mathrm{C}$ as previously described $(6,9)$. cGMP was assayed by the radioimmunoassay procedure of Steiner (11) and cAMP by 
the protein-binding method of Gilman (12). Both assays have been previously described in detail (13).

Determination of IPGE content of media. iPGE content was assessed as previously reported $(2,14,15) .\left[{ }^{3} \mathrm{H}\right] \mathrm{PGE}_{2}$ $(1,500 \mathrm{cpm})$ was added to $1 \mathrm{ml}$ of medium before storage at $-20^{\circ} \mathrm{C}$. Acidified samples (pH 3-3.5) were extracted in $\mathrm{CHCl}_{3}$ and assayed for iPGE content within 2 wk. Recovery of iPGE, as estimated from $\left[{ }^{3} \mathrm{H}\right] \mathrm{PGE}_{2}$, was $65-70 \%$. PGE was determined by radioimmunoassay, with antiserum obtained commercially (Regis Chemical Co., Morton Grove, IL). When plotted as logit-log functions, standard curves were linear from 0.1 to $10 \mathrm{ng} \mathrm{PGE} /$ tube.

High-performance liquid chromatography (HPLC) separation of $\left[{ }^{14} \mathrm{C}\right]$ arachidonate metabolites in media of colonic incubates. Colonic segments from untreated rats were incubated for $30 \mathrm{~min}$ at $37^{\circ} \mathrm{C}$ in $2 \mathrm{ml}$ each of medium 199incubation buffer, which contained $0.6 \mu \mathrm{Ci}\left[{ }^{14} \mathrm{C}\right]$ arachidonate $(1 \mu \mathrm{M})$. At the end of $30 \mathrm{~min}$, PG were extracted from the media as described by Green et al. (16). The following unlabeled standards were routinely added to each sample: 6keto-PGF $\mathrm{PG}_{1 \alpha}$, thromboxane $\mathrm{B}_{2}\left(\mathrm{TXB}_{2}\right), \mathrm{PGF}_{2 \alpha}, \mathrm{PGE}_{2}, \mathrm{PGD}_{2}$, 13,14-dihydro-15-keto- $\mathrm{PGF}_{2 \alpha}, 13,14$-dihydro-15-keto-PGE and $\mathrm{PGA}_{2}$. Elution of standards was monitored by absorption at $214 \mathrm{~nm}$. The system used adequately separated all of these standards. HPLC was conducted as described by Terragno et al., (17) with a $\mu$ Bondapak $\mathrm{Cl} 8$ reverse-phase column. The solvent system used was $0.017 \mathrm{M} \mathrm{H} \mathrm{H}_{3} \mathrm{PO}_{4} / \mathrm{CH}_{3} \mathrm{CN}$ $(67.2: 32.8, \mathrm{vol} / \mathrm{vol})$ at a flow rate of $1.7 \mathrm{ml} / \mathrm{min}$. Fractions were collected every $30 \mathrm{~s}$ and counted in the scintillation counter. Recovery of PG, as estimated by recovery of $\left[{ }^{3} \mathrm{H}\right] \mathrm{PGE}_{2}$ was routinely $80-85 \%$. Greater than $90 \%$ of the counts recovered from the HPLC column cochromatographed with the standards used.

Autoradiography. Rats were injected with indomethacin or vehicle as described above. $\left[{ }^{3} \mathrm{H}\right] \mathrm{d}$ Thd $(50 \mu \mathrm{Ci} /$ rat i.p. $)$ was injected $1 \mathrm{~h}$ after the last injection of indomethacin. $2 \mathrm{~h}$ later, rats were killed. Autoradiographs were prepared by standard techniques (18). Distal colonic segments were fixed in 3:1 methanol/acetic acid, sectioned to a thickness of 5 $\mu \mathrm{m}$ and mounted on glass slides. The slides were coated with NTB-2 and stored in the dark for 3 wk. The slides were developed (Kodak D10), fixed (Kodak 197-1746; Eastman Kodak Co., Rochester, NY) and poststained with hematoxylin and eosin. The proportion of labeled cells was determined by counting 30 crypts in each specimen. A cell was considered labeled if four or more granules overlayed the nucleus.

Extraction and assay of DNA. DNA content of the colonic mucosa was extracted as previously described (6). Aliquots were assayed for DNA by the diphenylamine procedure (19) and counted in the scintillation counter. Protein was determined by the method of Lowry et al. (20).

Statistics. Statistical significance between mean values was determined by Student's $t$ test for unpaired data. The results obtained from the vehicle $(50 \mathrm{mM}$ Tris, $\mathrm{pH} 7.4$ )treated control group did not differ from those obtained with the untreated control group and were combined. Experiments were repeated three to four times as indicated in the text, and the average of replicate determinations for a given parameter from each experiment was entered as a single value ( $\mathrm{df}=6$ or 4 , comparing any two parameters by unpaired $t$ test) for the purposes of statistical analysis.

\section{RESULTS}

Fig. 1 shows the separation of $\left[{ }^{14} \mathrm{C}\right]$ arachidonate metabolites formed during a 30 -min incubation of distal colonic segments from untreated rats. The relative amounts formed were $\mathrm{PGE}_{2} \gg \mathrm{PGD}_{2}>13$,14-dihydro15-keto-PGE PG $_{2}>\mathrm{PGF}_{2 \alpha}=\mathrm{TXB}_{2}=6$-keto-PGF $1 \alpha$ $>$ 13,14-dihydro-15-keto-PGF ${ }_{2 \alpha}$. The predominant labeled PG product formed by the colon is $\mathrm{PGE}_{2}$, accounting for $55 \%$ of the total PG products recovered when $\mathrm{PGE}_{2}$ plus the 13,14-dihydro-15-keto metabolite are combined. Addition of indomethacin $(0.25 \mathrm{mM})$ to the colon incubation medium abolished accumulation of all labeled PG shown in Fig. 1, whereas imadazole $(5.0 \mathrm{mM})$ selectively abolished accumulation of label eluting at the same retention time as standard $\mathrm{TXB}_{2}$.

Table I illustrates the effects of treatment of rats with indomethacin or aspirin on the in vivo incorporation of $\left[{ }^{3} \mathrm{H}\right] \mathrm{d}$ Thd into DNA of colonic mucosal scrapings and of isolated colonic epithelial cells. In these studies $\left[{ }^{3} \mathrm{H}\right] \mathrm{dTh}$ was administered to rats $2 \mathrm{~h}$ before they were killed. A portion of the colon was routinely examined by light microscopy after fixation in formalin and staining with hematoxylin and eosin. By light microscopy, colonic segments from aspirin- or indomethacin-treated rats were histologically normal and indistinguishable from those obtained from untreated rats. Specifically, there was no evidence of mucosal injury, inflammation, or change of colonic crypt height or cellularity in the rats treated with these drugs. As shown in Table $I$, the incorporation of $\left[{ }^{3} \mathrm{H}\right] \mathrm{d}$ Thd into DNA was enhanced approximately twofold in mucosa scraped from distal colon of rats that had been treated with indomethacin or aspirin, compared with control. As also shown in Table I, $\left[{ }^{3} \mathrm{H}\right] \mathrm{dThd}$ incorporation into DNA was approximately eightfold higher in proliferative compared with superficial epithelial cells from colons of rats, demonstrating the separation of these two epithelial cell pools (9). Proliferative cells isolated from rats treated with indomethacin or aspirin demonstrated incorporation of $\left[{ }^{3} \mathrm{H}\right] \mathrm{dTh}$ into DNA that was approximately threefold higher than control. In the superficial cell pool from the rats treated with indomethacin or aspirin, $\left[{ }^{3} \mathrm{H}\right] \mathrm{d}$ Thd incorporation into DNA was 1.5-2-fold higher than corresponding control values. However, autoradiographs of distal colon from control and indomethacintreated rats indicated that enhanced DNA synthesis in the experimental rats occurred predominantly in epithelial cells of the lower one-third of the crypts (Fig. 2). No granules were seen in the upper third of the colonic crypt of either control or indomethacintreated rats (data not shown). The percentage of cells labeled in the lower one-third of the colonic crypt was approximately twofold higher in rats treated with indomethacin compared with vehicle controls (indomethacin, $48 \pm 3 \%$; control, $26 \pm 2 \%$ ). The fraction of cells labeled in the middle third of the colonic crypts 


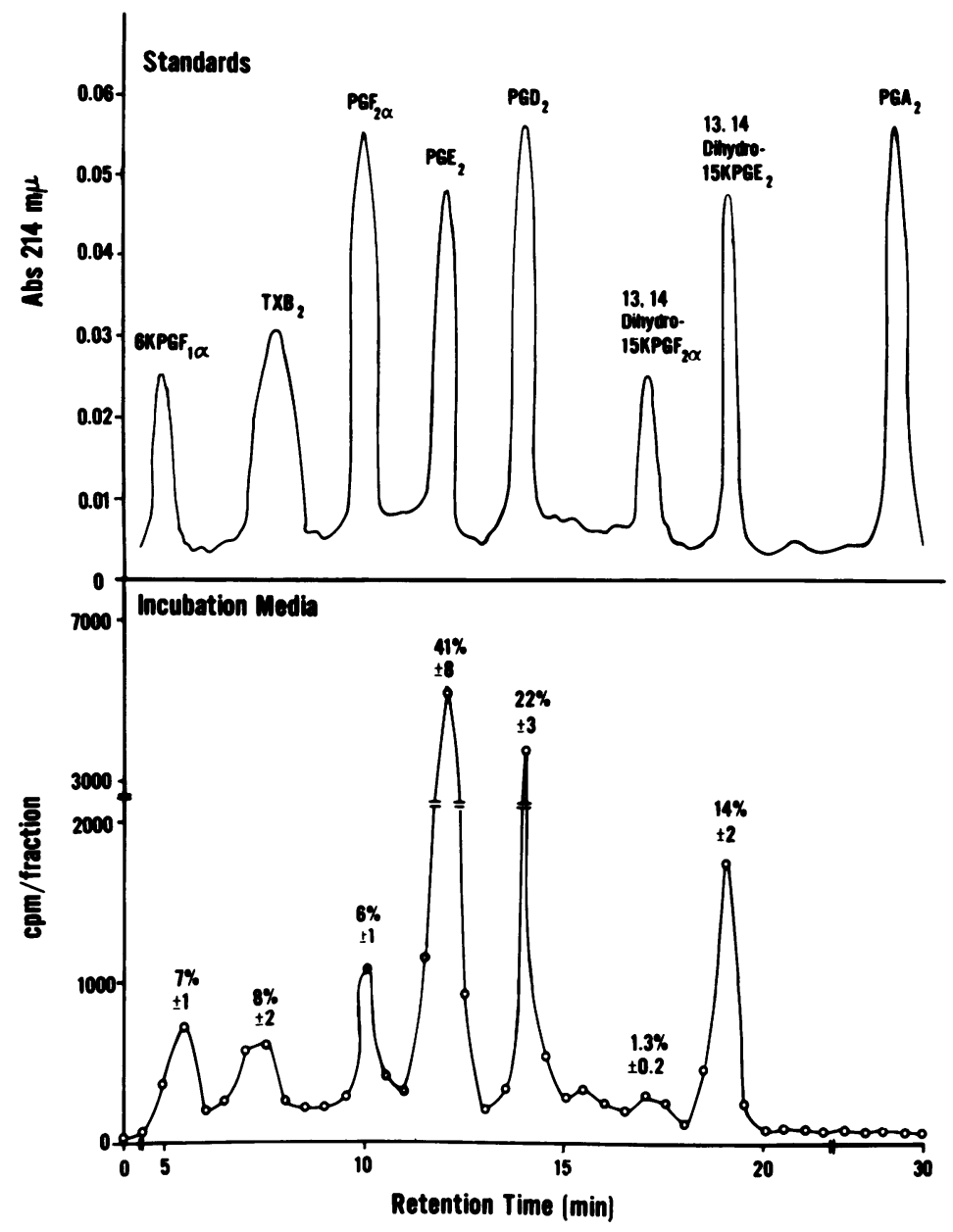

FIGURE 1 Separation of PG standards and $\left[{ }^{14} \mathrm{C}\right]$ arachidonate metabolites of incubated rat colon by HPLC. Distal colon segments from control rats were incubated in $2 \mathrm{ml}$ of medium 199incubation buffer for $30 \mathrm{~min}$ at $37^{\circ} \mathrm{C}$ with $0.6 \mu \mathrm{Ci}$ of $\left[{ }^{14} \mathrm{C}\right]$ arachidonate $(1 \mu \mathrm{M})$. PG were extracted from the medium, mixed with the PG standards shown, and injected onto a $\mu$ Bondapak $\mathrm{Cl} 8$ reverse-phase column. The solvent system used was $0.017 \mathrm{M} \mathrm{H}_{3} \mathrm{PO}_{4} / \mathrm{CH}_{3} \mathrm{CN}$ (67.2:32.8, $\mathrm{vol} / \mathrm{vol}$ ) at a flow rate of $1.7 \mathrm{ml} / \mathrm{min}$. Fractions were collected every $30 \mathrm{~s}$ and counted in the scintillation counter. Elution of standards is shown at top and elution of $\left[{ }^{14} \mathrm{C}\right]$ arachidonate metabolites is illustrated at bottom. Results shown for $\left[{ }^{14} \mathrm{C}\right]$ arachidonate metabolites of incubated distal colonic segments are means \pm SE of HPLC analyses of three separate incubations.

from either control or indomethacin-treated rats did not differ significantly, and each was much less than that observed in the lower crypts (Fig. 2).

$\left[{ }^{3} \mathrm{H}\right] \mathrm{d}$ Thd incorporation into mucosal DNA was also examined ex vivo. In these studies, rats were treated with indomethacin or aspirin as described above and segments of excised distal colon were then immediately incubated for $1 \mathrm{~h}$ at $37^{\circ} \mathrm{C}$ in the presence of $\left[{ }^{3} \mathrm{H}\right] \mathrm{dThd}$. Indomethacin and aspirin were not present in these incubates. As shown in Table II, analogous to the changes in in vivo incorporation of $\left[{ }^{3} \mathrm{H}\right] \mathrm{dTh}$ into mucosal DNA, treatment with indomethacin or aspirin enhanced ex vivo $\left[{ }^{3} \mathrm{H}\right] \mathrm{d}$ Thd incorporation into DNA of mucosal scrapings. In separate experiments (data not shown), in vitro total tissue uptake of $\left[{ }^{3} \mathrm{H}\right] \mathrm{dThd}$ by colonic mucosa was the same in indomethacin- or aspirin-treated vs. control rats. This was assessed by the $\left[{ }^{3} \mathrm{H}\right] \mathrm{dTh}$ remaining in the soluble fraction after precipitation of DNA from the mucosal extracts. As is also shown in Table II, treatment with indomethacin or aspirin in vivo suppressed early ex vivo media iPGE accumulation by $80-85 \%$, and significantly reduced cAMP content of mucosal scrapings from the same incubates. By contrast, cGMP content was not signif- 
TABLE I

Effects of Treatment with Indomethacin or Aspirin on In Vivo $\left[{ }^{3} H\right] d$ Thd Incorporation into DNA of Mucosal Scrapings and Isolated Superficial and Proliferative Colonic Epithelial Cells

\begin{tabular}{llll}
\hline \multicolumn{1}{c}{ Treatment } & Mucosa & $\begin{array}{c}\text { Superficial } \\
\text { cells }\end{array}$ & $\begin{array}{c}\text { Proliferative } \\
\text { cells }\end{array}$ \\
\hline \multicolumn{2}{c}{$d p m / \mu g$ DNA } \\
Control & $12 \pm 2$ & $2.7 \pm 0.4$ & \\
Indomethacin & $22 \pm 3^{\circ}$ & $5.1 \pm 0.6^{\circ}$ & $69 \pm 8^{\circ}$ \\
Aspirin & $25 \pm 4^{\circ}$ & $3.9 \pm 0.6^{\circ}$ & $57 \pm 6^{\circ}$ \\
\hline
\end{tabular}

In each indomethacin experiment, groups of six rats each were injected subcutaneously with either indomethacin $(5 \mathrm{mg} / \mathrm{kg})$ or

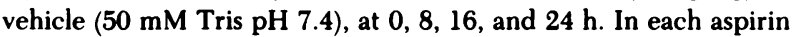
experiment, groups of six rats were fed aspirin $(0.5 \mathrm{~g} / 100 \mathrm{~g}$ diet $)$ or standard rat laboratory chow for $3 \mathrm{~d}$. $\left[{ }^{3} \mathrm{H}\right] \mathrm{dThd}(50 \mu \mathrm{Ci} / \mathrm{rat})$ was injected $1 \mathrm{~h}$ after the final indomethacin injection or $72 \mathrm{~h}$ after introduction of aspirin. Rats were killed $2 \mathrm{~h}$ after $\left[{ }^{3} \mathrm{H}\right] \mathrm{dThd}$ injection. The mucosa was scraped from a portion of each of the colons and the remainder used for isolation of superficial and proliferative epithelial cells. $\left[{ }^{3} \mathrm{H}\right] \mathrm{dTh}$ incorporation into DNA of the scraped mucosa and superficial and proliferative cells was then determined. Values from the indomethacin (vehicle) and aspirin control groups did not differ and were combined. Epithelial cells isolated from two rat colons of the same experimental group were combined before extraction and assay of DNA. Results shown are means \pm SE of determinations on mucosal scrapings or epithelial cells from four separate indomethacin and aspirin experiments $(\mathrm{df}=6)$.

- $P$ at least $<0.01$, compared with corresponding value in the control group.

icantly different in mucosa from rats treated with indomethacin or aspirin vs. control. Separate segments prepared from the same colons were used for the assessment of ex vivo $\left[{ }^{3} \mathrm{H}\right] \mathrm{dThd}$ incorporation, and for the cyclic nucleotide and iPGE determinations shown in Table II.

Fig. 3 illustrates the reversal of the effects of in vivo treatment with indomethacin on colonic iPGE production during prolonged incubation of the segments in vitro in the absence of indomethacin. Consistent with results of Table II, indomethacin treatment suppressed by $\sim 85 \%$, the accumulation of media iPGE during the first hour of incubation, compared with vehicle-treated controls. Media iPGE in incubates of colonic segments from indomethacin-treated rats increased progressively during the following 1-h incubation periods, and returned to control levels by the fourth hour of in vitro incubation of colon in the absence of indomethacin.

Table III shows the effects of treatment of rats in vivo with indomethacin, followed by the subsequent incubation of resected colon segments for $6 \mathrm{~h}$ in either the presence or absence of indomethacin. Treatment of rats with indomethacin followed by in vitro incubation of colonic segments from these rats with indomethacin for $6 \mathrm{~h}$ was associated with persistent enhancement of in vitro $\left[{ }^{3} \mathrm{H}\right] \mathrm{dTh}$ incorporation into mucosal DNA, compared with colons not exposed to indomethacin in vivo or in vitro. Mucosal cAMP content and iPGE synthesis by segments from indomethacin-treated rats also remained significantly depressed when incubated with indomethacin for $6 \mathrm{~h}$. By contrast, when colonic segments from rats treated with indomethacin were incubated for $6 \mathrm{~h}$ in the absence of indomethacin, iPGE accumulation in the media and mucosal cAMP content rose to levels observed in colon with no in vivo or in vitro exposure to indomethacin. Moreover, $\left[{ }^{3} \mathrm{H}\right] \mathrm{dTh}$ incorporation into mucosal DNA in colonic segments from indomethacin-treated rats that were incubated without indomethacin for $6 \mathrm{~h}$ fell toward control values, and after $24 \mathrm{~h}$ of incubation in the absence of indomethacin, did not differ from control values (data not shown). These results demonstrated that the effects of in vivo treatment with indomethacin on $\left[{ }^{3} \mathrm{H}\right] \mathrm{d}$ Thd incorporation into mucosal DNA, mucosal cAMP, and iPGE were all reversible by prolonged incubation of colon in vitro without the drug.

Table IV illustrates the effects of in vitro addition of indomethacin on mucosal cAMP and $\left[{ }^{3} \mathrm{H}\right] \mathrm{dThd}$ incorporation into mucosal DNA of colonic segments from control or indomethacin-treated rats during 6-h incubations. Analogous to the results shown in Table III, when colonic segments from rats treated with indomethacin were incubated for $6 \mathrm{~h}$ in the absence of the drug, mucosal cAMP returned to control levels (control, $4.4 \pm 0.5 \mathrm{pmol} / \mathrm{mg}$ protein; indomethacintreated, $4.6 \pm 0.7 \mathrm{pmol} / \mathrm{mg}$ protein). In the absence of indomethacin in vitro, $\left[{ }^{3} \mathrm{H}\right] \mathrm{dThd}$ incorporation into DNA by colonic mucosa of indomethacin-treated rats also fell toward control values (Table IV). Of note, when colonic segments obtained from control rats (no in vivo indomethacin) were incubated for $6 \mathrm{~h}$ in the presence of indomethacin, there was a significant reduction in mucosal cAMP (Table IV) and a marked reduction (>95\%) of media iPGE (data not shown), compared with values in control colon segments not exposed to indomethacin in vitro. However, in contrast to the findings in colonic segments from rats given indomethacin in vivo, $\left[{ }^{3} \mathrm{H}\right] \mathrm{dTh}$ incorporation into DNA of mucosa from colonic segments exposed to indomethacin only in vitro (Table IV) was not elevated compared with basal values (no in vivo or in vitro exposure to indomethacin). Moreover, 24-h incubations of colonic segments from control rats with either indomethacin $(0.25 \mathrm{mM})$ or aspirin $(0.5 \mathrm{mM})$ failed to alter $\left[{ }^{3} \mathrm{H}\right] \mathrm{d}$ Thd incorporation into mucosal DNA in vitro, despite significant reductions $(30 \%)$ in the cAMP 

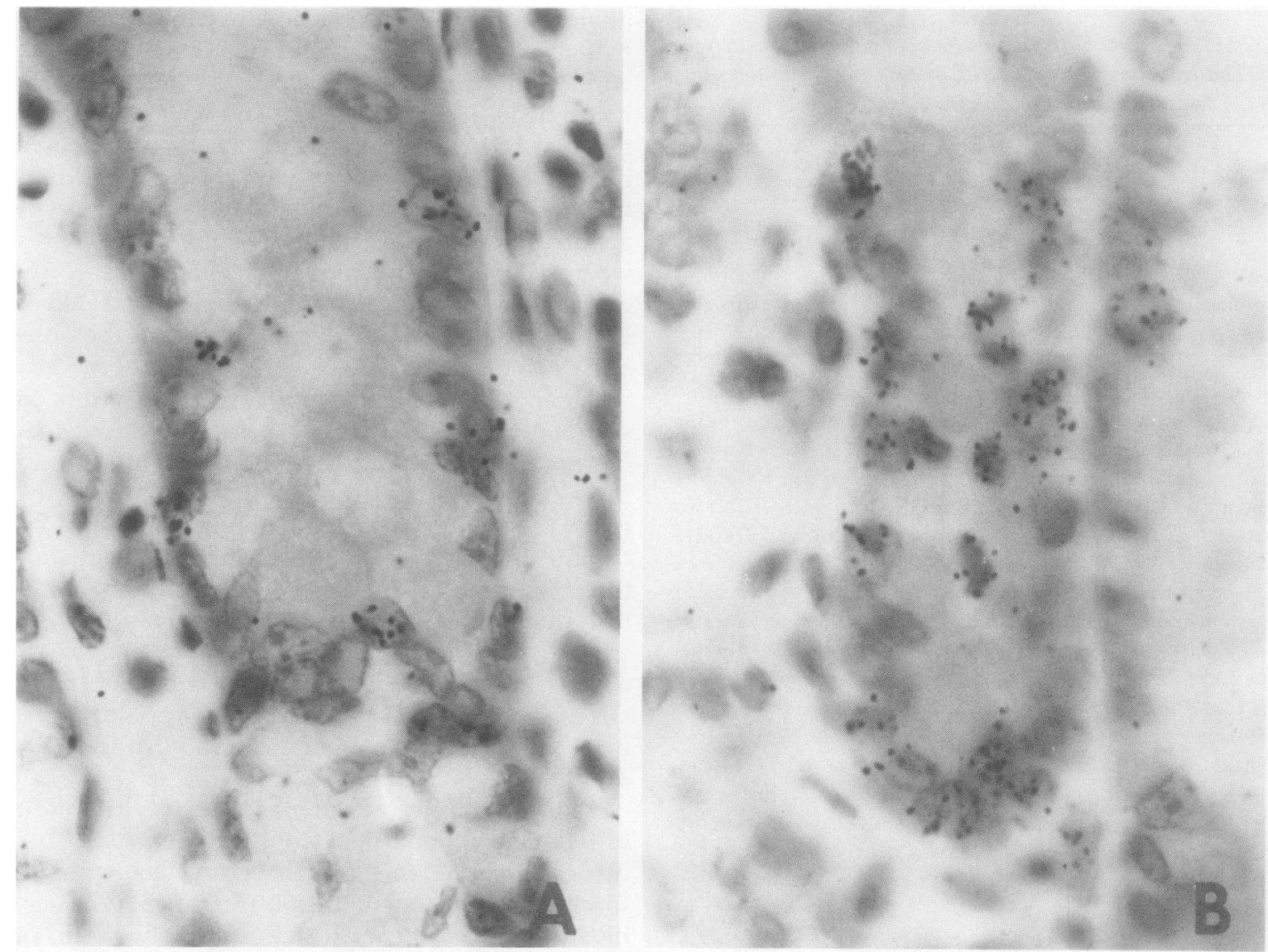

Figure 2 Autoradiography. The lower third of the colonic crypt derived from vehicle or indomethacin-treated rats is shown. Rats were injected with vehicle $(A)$ or indomethacin $(B)$ at 8-h intervals for $24 \mathrm{~h}$ as described in detail in Methods. $\left[{ }^{3} \mathrm{H}\right] \mathrm{dThd}$ was administered in vivo and rats were killed $2 \mathrm{~h}$ after the injection of $\left[{ }^{3} \mathrm{H}\right] \mathrm{dThd}$. Magnification, $\times 1,600$.

content of the mucosa and marked reductions (95\%) in media iPGE, compared with corresponding values in colonic incubates not containing indomethacin or aspirin (data not shown).

As also shown in Table IV, exogenous $\mathrm{PGE}_{2}, \mathrm{PGD}_{2}$, $\mathrm{PGF}_{2 \alpha}$, or $\mathrm{PGI}_{2}\left(10^{-4}-10^{-5} \mathrm{M}\right)$ all significantly suppressed $\left[{ }^{3} \mathrm{H}\right] \mathrm{d}$ Thd incorporation into mucosal DNA in segments from control rats. Suppression of $\left[{ }^{3} \mathrm{H}\right] \mathrm{dThd}$ incorporation into DNA by these PG was associated with two- to fourfold increases in colonic mucosal cAMP content at $6 \mathrm{~h}$ (Table IV). At $10^{-4} \mathrm{M}$, all of the exogenous PG significantly increased mucosal cAMP within $5 \mathrm{~min}$ after addition, the earliest time point examined. Peak increases occurred at $10 \mathrm{~min}$. Some secondary decline in cAMP from the peak levels was evident by $30 \mathrm{~min}$ after addition of the PG, but, as shown in Table IV, still remained above control values at $6 \mathrm{~h}$. The relative mucosal cAMP responses to the various $\mathrm{PG}$ at these earlier time points were as shown in Table IV, with $10^{-4} \mathrm{M} \mathrm{PGE}_{2}$ and $\mathrm{PGI}_{2}$ inducing greater increases than $\mathrm{PGD}_{2}$ or $\mathrm{PGF}_{2 \alpha}$. With $10^{-4} \mathrm{M}$ $\mathrm{PGE}_{2}$, peak $(10 \mathrm{~min})$ increases in mucosal cAMP were five- to sevenfold over control values. This peak response was followed by a secondary decline in cAMP evident by $30 \mathrm{~min}$ (three- to fourfold over control). However, mucosal cAMP of segments incubated with $10^{-4}$ or $10^{-5} \mathrm{M} \mathrm{PGE}_{2}$ remained significantly higher than control at $6 \mathrm{~h}$, as shown in Table IV. $\mathrm{PGE}_{2}$ at $10^{-6} \mathrm{M}$ or $5 \times 10^{-7} \mathrm{M}$ also significantly increased mucosal cAMP (approximately two- and 1.5-fold over control, respectively, at $10 \mathrm{~min}$ ). Both these concentrations of $\mathrm{PGE}_{2}$ also suppressed DNA synthesis by $\sim 30 \%$ in 6 -h incubations. By contrast, $\mathrm{PGE}_{2}$ from $10^{-7}$ to $10^{-9} \mathrm{M}$ was without detectable effect on mucosal cAMP when examined at $10 \mathrm{~min}, 1 \mathrm{~h}$, or $6 \mathrm{~h}$, or on DNA synthesis in 6-h incubations. On the basis of the limited equivalent concentrations $\left(10^{-4}\right.$ and $\left.10^{-5} \mathrm{M}\right)$ of the various PG tested and a comparison of the cAMP 
TABLE II

Effects of Treatment of Rats with Inhibitors of PG Synthesis on $\left[{ }^{3} H\right] d T h d$ Incorporation into Colonic Mucosal DNA, cAMP, and cGMP Content and Media iPGE Accumulation Examined Ex Vivo

\begin{tabular}{|c|c|c|c|c|}
\hline Treatment & [ ${ }^{3} \mathrm{H}$ ]dThd & CAMP & cGMP & iPGE \\
\hline & $\begin{array}{c}d p m / \mu g \\
D N A\end{array}$ & \multicolumn{2}{|c|}{$\mathrm{pmol} / \mathrm{mg}$ protein } & $\mathrm{ng} / \mathrm{mg}$ tissue \\
\hline Control & $21 \pm 4$ & $5.1 \pm 0.7$ & $0.61 \pm 0.09$ & $0.24 \pm 0.03$ \\
\hline Indomethacin & $55 \pm 8^{\circ}$ & $3.0 \pm 0.4^{\circ}$ & $0.49 \pm 0.07$ & $0.04 \pm 0.007^{\circ}$ \\
\hline Aspirin & $42 \pm 6^{\circ}$ & $3.4 \pm 0.5^{\circ}$ & $0.52 \pm 0.07$ & $0.05 \pm 0.009^{\circ}$ \\
\hline
\end{tabular}

In each experiment, groups of six rats were injected with indomethacin, fed aspirin, or served as controls as described in the footnote to Table I. Control groups were untreated or received the indomethacin vehicle. The distal colons were excised and colonic segments $(1 \times 1 \mathrm{~cm})$ incubated for $1 \mathrm{~h}$ in medium 199-incubation buffer. $\left[{ }^{3} \mathrm{H}\right] \mathrm{dThd}(0.5 \mu \mathrm{Ci} / \mathrm{ml})$ was present in some of the incubates. For determination of $\left[{ }^{3} \mathrm{H}\right] \mathrm{dThd}$ incorporation into mucosal DNA, five distal colon segments from each rat were used, whereas for determination of cAMP, cGMP, and iPGE, three segments from the same colons used for $\left[{ }^{3} \mathrm{H}\right] \mathrm{dTh}$ determination were incubated. Values from the indomethacin vehicle and untreated control groups did not differ and were combined. Results shown are means $\pm \mathrm{SE}$ of determinations from three separate experiments ( $\mathrm{df}=4)$.

- $P$ at least $<0.01$, compared with corresponding value in control rats.

responses to $10^{-4} \mathrm{M}$ at $5 \mathrm{~min}, 30 \mathrm{~min}, 1 \mathrm{~h}$, and $6 \mathrm{~h}$ after addition, $\mathrm{PGD}_{2}$ and $\mathrm{PGF}_{2 \alpha}$ appeared to be less effective than $\mathrm{PGE}_{2}$ and $\mathrm{PGI}_{2}$ as stimuli of $\mathrm{cAMP}$ and as suppressors of $\left[{ }^{3} \mathrm{H}\right] \mathrm{d}$ Thd incorporation into DNA. However, more detailed studies would be required to establish the relative potency of these PG with certainty. Addition of dibutyryl (DB)cAMP also suppressed $\left[{ }^{3} \mathrm{H}\right] \mathrm{dTh}$ incorporation into mucosal DNA in control colonic segments (39-43\%), whereas dibutyryl (DB)cGMP was without effect. In vitro $\left[{ }^{3} \mathrm{H}\right] \mathrm{dThd}$ incorporation into DNA was elevated in the mucosa of colonic segments from rats treated with indomethacin in vivo and then subsequently incubated with this agent (Table IV). Exogenous $\mathrm{PGE}_{2}, \mathrm{PGI}_{2}, \mathrm{PGD}_{2}$, or $\mathrm{PGF}_{2 \alpha}\left(10^{-4}-10^{-5} \mathrm{M}\right)$ all suppressed $\left[{ }^{3} \mathrm{H}\right] \mathrm{dTh}$ incorporation into mucosal DNA in segments from the indomethacin-treated rats. However, during 6-h incubations with these same test agents, $\left[{ }^{3} \mathrm{H}\right] \mathrm{dThd}$ incorporation into mucosal DNA remained significantly higher in segments from indomethacin-treated rats compared with corresponding values in control segments (Table IV). As is also shown in Table IV, mucosal cAMP content was significantly lower in segments from indomethacin-treated rats compared with control. However, addition of $\mathrm{PGE}_{2}, \mathrm{PGI}_{2}, \mathrm{PGD}_{2}$, or $\mathrm{PGF}_{2 \alpha}$ in vitro elevated mucosal cAMP to the same absolute level in segments from indomethacin-treated and control rats. Analogous effects of these exogenous PG and DBcAMP were observed on in vitro $\left[{ }^{3} \mathrm{H}\right] \mathrm{dThd}$ incorporation of colonic segments from rats treated with aspirin (data not shown).

\section{DISCUSSION}

The colonic epithelium undergoes continuous and rapid renewal. This process follows a well ordered sequence in which relatively undifferentiated cells at the base of the crypt show the greatest proliferative activity and serve as a source of new cells in the renewal process $(21)$. As cells from the lower crypt migrate into the upper one-third of the colonic crypt, proliferative activity ceases and differentiation occurs (21). The process of colonic epithelial cell migration takes 2-3

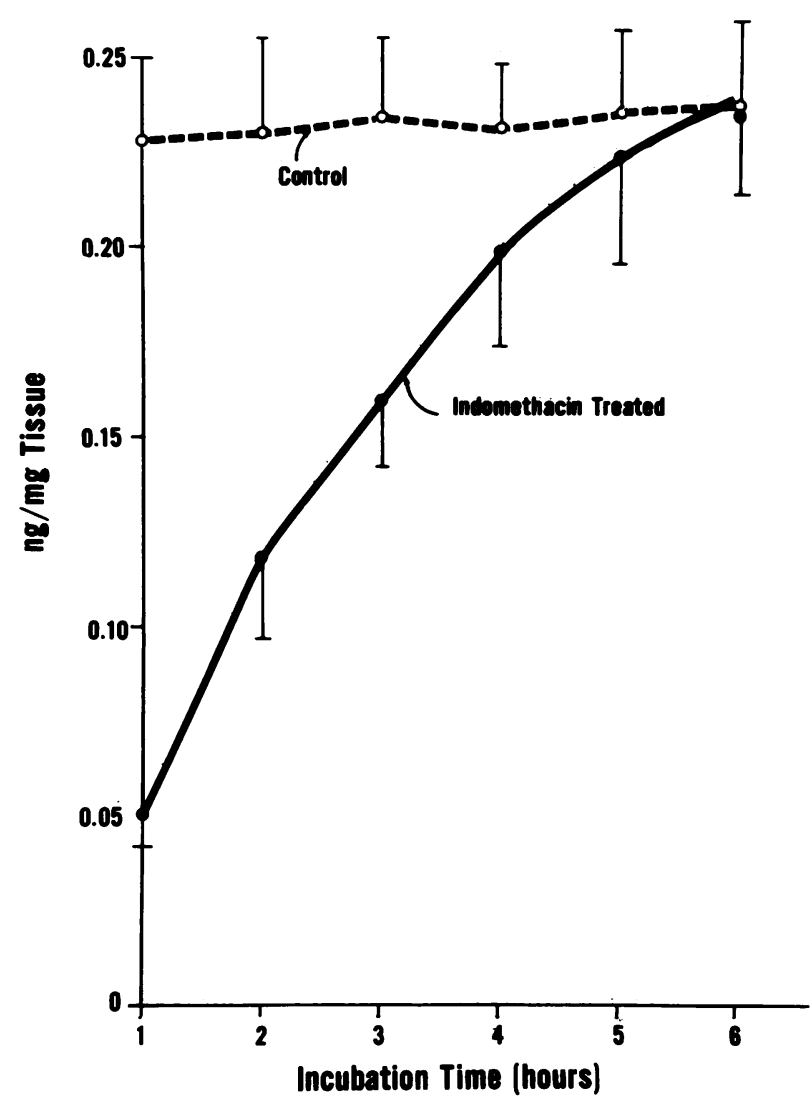

Figure 3 Time course of reversal of indomethacin-induced alterations in media IPGE of incubated colonic segments. In each experiment, six rats were treated with indomethacin $(O)$ or vehicle $(O)$ in vivo as described in the legend to Table II. Three segments from each colon were then incubated sequentially for a total of $6 \mathrm{~h}$ in medium 199-incubation buffer without added indomethacin. The medium was changed every hour and iPGE content determined. Results are means $\pm \mathrm{SE}$ of values from three separate experiments $(\mathrm{df}=4)$. 
TABLE III

In Vitro Reversal of Alterations in $\left[{ }^{3} \mathrm{H}\right] \mathrm{dTh}$ Incorporation into Mucosal DNA and cAMP and Media iPGE Accumulation in Colonic Segments from Indomethacin-treated Rats

\begin{tabular}{|c|c|c|c|c|}
\hline \multicolumn{2}{|c|}{ Indomethacin } & \multirow[b]{2}{*}[{}^{3}\mathrm{H}]{$\mathrm{dThd}$} & \multirow[b]{2}{*}{ cAMP } & \multirow[b]{2}{*}{ iPGE } \\
\hline In vivo & In vitro & & & \\
\hline & & $\begin{array}{c}d p m / \mu g \\
D N A\end{array}$ & $\begin{array}{c}\mathrm{pmol} / \mathrm{mg} \\
\text { protein }\end{array}$ & $n g / m g$ tissue \\
\hline- & - & $53 \pm 9$ & $5.6 \pm 0.8$ & $0.38 \pm 0.06$ \\
\hline+ & + & $127 \pm 16^{\circ}$ & $3.2 \pm 0.5^{\circ}$ & $0.021 \pm 0.003^{\circ}$ \\
\hline+ & - & $78 \pm 12^{\circ} \ddagger$ & $5.8 \pm 0.7 \ddagger$ & $0.43 \pm 0.07 \ddagger$ \\
\hline
\end{tabular}

Where indicated under indomethacin in vivo, rats were treated with indomethacin as described in Table I. Five $\left(\left[{ }^{3} \mathrm{H}\right] \mathrm{dThd}\right)$ or three (cAMP and iPGE) segments from each rat colon were incubated for $6 \mathrm{~h}$ at $37^{\circ} \mathrm{C}$. Media were changed at 2 -h intervals. $\left[{ }^{3} \mathrm{H}\right] \mathrm{dThd}$ was present for the final $2 \mathrm{~h}$. Where indicated under indomethacin in vitro, the drug $(0.25 \mathrm{mM})$ was either present or absent during the entire 6 -h period of incubation. Results are means $\pm S E$ of determinations from three separate experiments $(\mathrm{df}=4)$.

- $P$ at least $<0.01$, compared with corresponding value in the absence of indomethacin in vitro or in vivo.

$\ddagger P$ at least $<0.01$ comparing values of segments from rats exposed to indomethacin in vivo only with values obtained in colon exposed to indomethacin both in vivo and in vitro.

$\mathrm{d}$ in the rodent and 4-8 $\mathrm{d}$ in man (22). A constant epithelial cell pool is normally maintained by the dynamic equilibrium between cell proliferation in the lower crypt and cell loss at the surface $(21,22)$. The processes that control the proliferative activity of colonic epithelium are multiple, complex, and incompletely defined. They include intraluminal factors, such as food intake, hormones, and paracrines (22-25). The present study was undertaken to assess whether local PG synthesis participates in the modulation of proliferative activity of the colonic epithelium. Previous in vitro data supported the ability of exogenous $\mathrm{PGE}_{1}, \mathrm{PGE}_{2}$, or $\mathrm{PGF}_{2 \alpha}$ to suppress colonic mucosal DNA synthesis in cultured explants from both rabbit and rat $(5,6)$. Earlier studies have also demonstrated that $\mathrm{PGE}_{2}$ and $\mathrm{PGF}_{2 \alpha}$ are synthesized by colon (1). However, evidence that local alterations in colonic PG synthesis influence the proliferative activity of normal colonic epithelium has been lacking.

The current study demonstrates that the administration to rats of indomethacin or aspirin, two structurally distinct inhibitors of cyclooxygenase activity (26), acutely enhances colonic epithelial DNA synthesis in vivo. Increased $\left[{ }^{3} \mathrm{H}\right] \mathrm{d}$ Thd incorporation into DNA was observed in preparations of epithelial cells isolated from treated rats, as well as in scrapings (Table I). Thus, changes in total mucosal DNA synthesis reliably reflected the directional changes that occurred in the epithelial cell compartment. This stimulation was not attributable to enhanced epithelial renewal in response to histologically evident cell injury or inflammation. Autoradiographic studies provided no evidence that $24 \mathrm{~h}$ of treatment with indomethacin resulted in an extension of the normal proliferative zone of colonic epithelium (Fig. 2). Thus, the acute enhancement of DNA synthesis induced by cyclooxygenase inhibitors appears to occur mainly in the lower third of the crypt, the region that normally demonstrates proliferative activity (27). The small increase in $\left[{ }^{3} \mathrm{H}\right] \mathrm{dThd}$ incorporation observed in the superficial cell isolates may be due to minor contamination of this pool with proliferative cells from the lower zones. It is possible that the changes in DNA synthesis induced by indomethacin reflect an enhanced turnover of dividing lower crypt cells, with continued normal suppression of proliferative activity as these cells migrate up the crypt. However, more prolonged studies with indomethacin will be needed to exclude with certainty an eventual extension of the proliferative zone, described in colon of both rodent and man (27).

The stimulation of colonic mucosal DNA synthesis induced by treatment of rats with either indomethacin or aspirin was detectable during ex vivo incubation of colonic segments with $\left[{ }^{3} \mathrm{H}\right] \mathrm{dThd}$, performed immediately after colonic resection (Table II). The ex vivo data make it unlikely that the increases in $\left[{ }^{3} \mathrm{H}\right] \mathrm{dThd}$ incorporation observed in vivo were related to altered rates of delivery of injected $\left[{ }^{3} \mathrm{H}\right] \mathrm{dTh}$ to the colonic mucosa of rats treated with indomethacin or aspirin. Moreover, since $\left[{ }^{3} \mathrm{H}\right] \mathrm{dTh}$, recovered in the soluble cell fraction of colonic mucosa from control rats, did not differ from corresponding values in rats treated with indomethacin or aspirin, enhanced $\left[{ }^{3} \mathrm{H}\right] \mathrm{dTh}$ incorporation into DNA was not a simple function of greater uptake of label by colonic mucosa of the treated rats. The ex vivo studies also provide evidence that the doses of indomethacin and aspirin given to the rats were in fact effective in suppressing colonic PG synthesis, as monitored by changes in iPGE. Thus, iPGE, the major PG product of colonic segments (Fig. 1), was markedly reduced in 1-h incubates of segments resected from indomethacin- or aspirin-treated rats, compared with control (Table II). Suppression of iPGE synthesis was associated with both higher rates of $\left[{ }^{3} \mathrm{H}\right] \mathrm{dTh}$ incorporation into DNA and reduced mucosal content of cAMP. iPGE synthesis by colonic segments from indomethacin-treated rats remained suppressed for $3 \mathrm{~h}$ after resection (Fig. 3). However, after $4 \mathrm{~h}$ of incubation, iPGE formation by three segments returned to control levels (Fig. 3). This change was associated with a rise in mucosal cAMP content to control values and a fall in DNA synthesis (Table III). After $24 \mathrm{~h}$ of incubation without indomethacin, values in colon seg- 
TABLE IV

Effects of In Vitro Addition of Indomethacin, PG, DBcAMP, and DBcGMP on

$\left[{ }^{3} \mathrm{H}\right] d$ Thd Incorporation into DNA and cAMP of Colonic Segments from Control and Indomethacin-treated Rats

\begin{tabular}{|c|c|c|c|c|}
\hline \multirow[b]{2}{*}{ In vitro additions } & \multicolumn{2}{|c|}{ cAMP } & \multicolumn{2}{|c|}{ [ $\left.{ }^{3} \mathrm{H}\right) \mathrm{dThd}$} \\
\hline & Vehicle & Indomethacin & Vehicle & Indomethacin \\
\hline & \multicolumn{2}{|c|}{$\mathrm{pmol} / \mathrm{mg}$ protein } & \multicolumn{2}{|c|}{$d p m / \mu g D N A$} \\
\hline None & $4.4 \pm 0.5$ & $4.6 \pm 0.7$ & $49 \pm 6$ & $74 \pm 10 t$ \\
\hline Indomethacin & $3.1 \pm 0.4^{\circ}$ & $3.2 \pm 0.5^{\circ}$ & $51 \pm 7$ & $106 \pm 13^{\circ} t$ \\
\hline$+10^{-4} \mathrm{M} \mathrm{PGE}_{2}$ & $11 \pm 2^{\circ}$ & $10 \pm 1^{\circ}$ & $32 \pm 5^{\circ}$ & $55 \pm 8^{\circ} !$ \\
\hline$+10^{-5} \mathrm{M} \mathrm{PGE}_{2}$ & $13 \pm 2^{\circ}$ & $11 \pm 1^{\circ}$ & $35 \pm 6^{\circ}$ & $58 \pm 7^{\circ} !$ \\
\hline$+10^{-4} \mathrm{M} \mathrm{PGD}_{2}$ & $7.3 \pm 1^{\circ}$ & $7.5 \pm 1^{\bullet}$ & $37 \pm 5^{\circ}$ & $72 \pm 11^{\circ} !$ \\
\hline$+10^{-5} \mathrm{M} \mathrm{PGD}_{2}$ & $7.1 \pm 1^{\bullet}$ & $6.7 \pm 1^{\circ}$ & $36 \pm 6^{\circ}$ & $69 \pm 10^{\circ} \ddagger$ \\
\hline$+10^{-4} \mathrm{MPGI}_{2}$ & $10 \pm 2^{\bullet}$ & $12 \pm 2^{\circ}$ & $32 \pm 5^{\circ}$ & $61 \pm 9^{\circ} \downarrow$ \\
\hline$+10^{-5} \mathrm{M} \mathrm{PGI}_{2}$ & $12 \pm 1^{\bullet}$ & $10 \pm 1^{\circ}$ & $35 \pm 7^{\circ}$ & $58 \pm 7^{\bullet} \downarrow$ \\
\hline$+10^{-4} \mathrm{M} \mathrm{PGF}_{2 \alpha}$ & $6.7 \pm 1^{\circ}$ & $6.1 \pm 1^{\circ}$ & $37 \pm 5^{\circ}$ & $76 \pm 11^{\circ} !$ \\
\hline$+10^{-5} \mathrm{M} \mathrm{PGF}_{2 \alpha}$ & $6.4 \pm 1^{\bullet}$ & $6.9 \pm 1^{\bullet}$ & $36 \pm 6^{\circ}$ & $71 \pm 12^{\circ} 1$ \\
\hline$+10^{-4} \mathrm{M} \mathrm{DBcAMP}$ & - & - & $29 \pm 4^{\circ}$ & $53 \pm 6^{\circ} \downarrow$ \\
\hline$+10^{-5} \mathrm{M}$ DBcAMP & 一 & 一 & $31 \pm 5^{\circ}$ & $49 \pm 7^{\circ} \downarrow$ \\
\hline$+10^{-4} \mathrm{M}$ DBcGMP & 一 & 一 & $53 \pm 8$ & $102 \pm 13 t$ \\
\hline
\end{tabular}

Rats were treated with indomethacin or vehicle as described in the footnote to Table I. For the determination of $\left[{ }^{3} \mathrm{H}\right] \mathrm{dThd}$ incorporation into DNA, segments from each rat colon were incubated for $6 \mathrm{~h}$ in the medium 199-incubation buffer. The medium was changed every $2 \mathrm{~h}$ to fresh medium of the same composition. Test agents indicated under in vitro additions were present in the media for the entire $6 \mathrm{~h}$. $\left[{ }^{3} \mathrm{H}\right.$ ]dThd was present in the incubates indicated for the final $2 \mathrm{~h}$. For determination of cAMP, three segments from the same colons used to determine $\left[{ }^{3} \mathrm{H}\right] \mathrm{dTh}$ incorporation into DNA were incubated for $6 \mathrm{~h}$ at $37^{\circ} \mathrm{C}$. Where indicated under in vitro additions, indomethacin, PG, and exogenous cyclic nucleotides were present for the entire $6 \mathrm{~h}$. Results are means $\pm \mathrm{SE}$ of determinations from three separate experiments $(\mathrm{df}=4)$.

- $P<0.01$ compared, with corresponding value in the absence of an in vitro addition. $t P<0.01$ compared with corresponding value in vehicle-treated rats.

ments from rats treated with indomethacin had returned to control levels. By contrast, inclusion of indomethacin in 6-h incubates of colonic segments obtained from rats treated with indomethacin in vivo resulted in persistent suppression of iPGE formation that was associated with reduced mucosal cAMP levels and persistent enhancement of DNA synthesis, compared with segments from control rats. Of particular note, in vitro incubation of colonic segments from control rats (no exposure to indomethacin or aspirin in vivo) with indomethacin or aspirin for periods up to $24 \mathrm{~h}$ failed to alter $\left[{ }^{3} \mathrm{H}\right] \mathrm{dTh}$ incorporation into mucosal DNA, even though iPGE content of the incubates and mucosal cAMP levels were reduced by drug exposure in vitro only. These results indicate that inhibition of colonic PG synthesis and the concurrent reduction in mucosal cAMP are alone insufficient to stimulate colonic mucosal DNA synthesis. The observations strongly imply that additional factors were involved in the enhancement of DNA synthesis that was initi- ated in vivo in the setting of reduced colonic PG synthesis.

Conversely, on the basis of these and other considerations, it may be suggested that the net impact of local colonic PG synthesis is to inhibit the proliferative activity of the epithelium. Thus, time-dependent restoration of colonic PG synthesis to control levels in 6$h$ incubated segments from indomethacin-treated rats was accompanied by a fall in $\left[{ }^{3} \mathrm{H}\right] \mathrm{d}$ Thd incorporation into DNA toward control values. Moreover, addition of several exogenous PG $\left(\mathrm{PGE}_{2}, \mathrm{PGF}_{2 \alpha}, \mathrm{PGD}_{2}\right.$, or $\mathrm{PGI}_{2}$ ), each of which is formed by colonic segments and each of which increased colonic mucosal cAMP levels, suppressed both basal mucosal DNA synthesis and the enhanced rates of DNA synthesis characteristic of colonic segments from indomethacin- or aspirintreated rats (Table IV). The inhibitory influence of local PG production on epithelial cell proliferative activity in colon may play an important role in the orderly growth and differentiation of this rapidly re- 
newing cell population. Thus, changes in colonic PG synthesis may represent a pathway through which hormones and other factors influence the growth of colonic epithelium. Local PG production has also been implicated in the control of uterine epithelial cell growth (28).

As in the present study, previous observations have strongly suggested that the action of PG to inhibit colonic mucosal DNA synthesis is mediated through cAMP $(5,6)$. Another stimulus of colonic mucosal cAMP, vasoactive intestinal peptide, has also been shown to suppress DNA synthesis (6). In addition, we have previously found that the cAMP content of superficial (nonproliferative) epithelial cells isolated from normal rat colon is significantly higher than that of proliferative cells (9), whereas the cAMP content of colonic epithelium falls during the period of enhanced DNA synthesis that follows cell injury (6). Conversely, in vivo administration of DBcAMP has been reported to inhibit cell proliferation in rat colonic crypts (29). Notably, the cAMP content of both human colonic adenocarcinomas (13) and colonic tumors induced experimentally in rodents $(30)$ is lower than that of corresponding normal colonic mucosa.

In summary, the present data are consistent with a role for local colonic PG synthesis in the modulation of the proliferative activity of colonic epithelium. The effect of locally generated PG is suppression of DNA synthesis. However, enhancement of colonic mucosal DNA synthesis in response to inhibitors of PG synthesis was observed only when these agents were given in vivo, suggesting that additional factors were necessary to initiate DNA synthesis after depression of PG generation. The inhibitory effect of PG on colonic epithelial cell proliferation may be mediated through cAMP.

\section{ACKNOWLEDGMENTS}

The authors are indebted to Jeffrey Ahlers and A. Forrest Imhoff for excellent technical assistance and to Ms. Kathy Daum for typing the manuscript.

This work was supported by U. S. Public Health Service grant CA 31680 from the National Cancer Institute through the Large Bowel Cancer Project.

\section{REFERENCES}

1. Knapp, H. R., V. Oelz, B. J. Sweetman, and J. A. Oates. 1978. Synthesis and metabolism of prostaglandins $E_{2}$, $F_{2 \alpha}$, and $D_{2}$ by the rat gastrointestinal tract: stimulation by a hypertonic environment in vitro. Prostaglandins. 15:751-757.

2. Craven, P. A., and F. R. DeRubertis. 1981. Stimulation of rat colonic mucosal prostaglandin synthesis by calcium and carbamylcholine: relationship to alterations in cyclic nucleotide metabolism. Prostaglandins. 21:65-81.
3. Taub, M., M. J. Coyne, G. G. Bonorris, A. Chung, B. Coyne, and L. J. Schoenfield. 1978. Inhibition by propranalol of bile acid and PGE, stimulated cAMP and intestinal secretion. Am. J. Gastroenterol. 70:129-135.

4. Falconer, J. D., A. N. Smith, and M. A. Eastwood. 1978. Effects of bile salts and prostaglandins on colonic motility in the rabbit. In Gastrointestinal Motility in Health and Disease. H. L. Duthie, editor. MTP Press, Lancaster, England. 607-617.

5. Alpers, D. H., and G. W. Philpott. 1975. Control of DNA synthesis in normal rabbit colonic mucosa. Gastroenterology. 69:951-959.

6. DeRubertis, F. R., and P. A. Craven. 1980. Early alterations in rat colonic mucosal cyclic nucleotide metabolism and protein kinase activity induced by 1,2-dimethylhydrazine. Cancer Res. 40:4589-4598.

7. Tutton, P. J. M., and D. H. Barkla. 1980. Influence of prostaglandin analogues on epithelial cell proliferation and xenograft growth. Br. J. Cancer. 41:47-51.

8. Johansson, C., A. Aly, B. Kollberg, C. Rubio, T. Erikoinen, and H. F. Helander. 1983. Trophic actions of oral $E_{2}$ prostaglandins on the rat gastrointestinal mucosa. Adv. Prostaglandin Thromboxane Res. 12:403-407.

9. Craven, P. A., and F. R. DeRubertis. 1981. Cyclic nucleotide metabolism in rat colonic epithelial cells with different proliferative activities. Biochim. Biophys. Acta. 676:155-169.

10. Weiser, M. M. 1971. Intestinal epithelial cell surface membrane glycoprotein synthesis I: an indicator of cellular differentiation. J. Biol. Chem. 218:2536-2541.

11. Steiner, A. L., A. S. Pagliara, L. R. Chase, and M. D. Kipnis. 1972. Radioimmunoassay for cyclic nucleotides II adenosine 3'5'-monophosphate and guanosine $3^{\prime} 5$ monophosphate in mammalian tissues and body fluids. J. Biol. Chem. 247:1114-1120.

12. Gilman, A. G. 1970. A protein binding assay for adenosine 3'5'-cyclic monophosphate. Proc. Natl. Acad. Sci. USA. 67:305-312.

13. DeRubertis, F. R., R. Chayoth, and J. B. Field. 1979. The content and metabolism of cyclic adenosine $3^{\prime} 5^{\prime}$ monophosphate and cyclic guanosine $3^{\prime} 5^{\prime}$-monophosphate in adenocarcinoma of the human colon. J. Clin. Invest. 57:641-649.

14. Craven, P. A., R. K. Studer, and F. R. DeRubertis. 1981. Renal inner medullary prostaglandin synthesis. A calcium-calmodulin-dependent process suppressed by urea. J. Clin. Invest. 68:722-732.

15. Craven, P. A., and F. R. DeRubertis. 1982. Effects of vasopressin and urea on $\mathrm{Ca}^{2+}$-calmodulin-dependent renal prostaglandin E. Am. J. Physiol. 241:F649-F658.

16. Green, K., M. Hamberg, B. Samuelsson, and J. C. Frölich. 1978. Extraction and chromatographic procedures for purification of prostaglandins, thromboxanes, prostacyclin, and their metabolites. Adv. Prostaglandin Thromboxane Res. 5:15-38.

17. Terragno, A., R. Rydzik, and N. A. Terragno. 1981 High-performance liquid chromatography and UV detection for the separation and quantitation of prostaglandins. Prostaglandins. 21:101-112.

18. Stein, G. H., and R. Yanishevsky. 1979. Autoradiography. Methods Enzymol. 58:279-292.

19. Burton, K. A. 1956. A study of the conditions and mechanisms of the diphenylamine reaction for the colorimetric estimation of deoxyribonucleic acid. Biochem. J. 62:315-323.

20. Lowry, O. H., N. J. Rosebrough, A. L. Farr, and R. J. 
Randall. 1951. Protein measurement with the Folin phenol reagent. J. Biol. Chem. 193:265-275.

21. Lipkin, M. 1974. Proliferative changes in the colon. Dig. Dis. Sci. 19:1029-1032.

22. Eastwood, G. L. 1977. Gastrointestinal epithelial renewal. Gastroenterology. 72:962-975.

23. Enochs, M. R., and L. R. Johnson. 1977. Trophic effects of gastrointestinal hormones: physiologic implications. Fed. Proc. 36:1942-1947.

24. Williamson, R. C. N. 1978. Intestinal adaptation, part I. N. Engl. J. Med. 298:1393-1402.

25. Williamson, R. C. N. 1978. Intestinal adaptation, part II. N. Engl. J. Med. 298:1444-1450.

26. Dunn, M. J., and E. J. Zambroski. 1980. Renal effects of drugs that inhibit prostaglandin synthesis. Kidney Int. 18:609-622.
27. Lipkin, M. 1974. Phase 1 and phase 2 proliferative lesions of colonic epithelial cells in diseases leading to colonic cancer. Cancer (Phila.). 34:878-888.

28. Gal, D., M. L. Casey, J. M., Johnston, and P. C. MacDonald. 1982. Mesenchyme-epithelial interactions in human endometrium. Prostaglandin synthesis in separated cell types. J. Clin. Invest. 70:798-805.

29. Tutton, P. J. M., and D. H. Barkla. 1981. Effects of cyclic nucleotide derivatives on the growth of human colonic carcinoma xenografts and on cell production in the rat colonic crypt epithelium. Br. J. Cancer. 44:182-188.

30. Stevens, R. H., D. P. Loven, J. W. Osborne, J. P. Prall, and A. J. Lawson. 1977. Cyclic nucleotide concentrations in 1,2-dimethylhydrazine-induced rat colon adenocarcinoma. Cancer Lett. 4:27-33. 